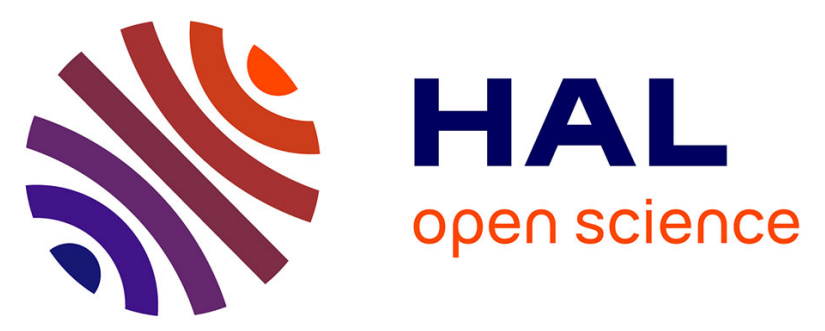

\title{
The customers for document supply in pharmacology : a case study from INIST in France (part 3)
}

Pascal Bador, Chérifa Boukacem-Zeghmouri, Thierry Lafouge, Hélène Prost, Joachim Schöpfel

\section{- To cite this version:}

Pascal Bador, Chérifa Boukacem-Zeghmouri, Thierry Lafouge, Hélène Prost, Joachim Schöpfel. The customers for document supply in pharmacology: a case study from INIST in France (part 3). Interlending and Document Supply, 2007, 35 (3), pp.138-144. 10.1108/02641610710780809 . sic_00380730

\author{
HAL Id: sic_00380730 \\ https://archivesic.ccsd.cnrs.fr/sic_00380730
}

Submitted on 4 May 2009

HAL is a multi-disciplinary open access archive for the deposit and dissemination of scientific research documents, whether they are published or not. The documents may come from teaching and research institutions in France or abroad, or from public or private research centers.
L'archive ouverte pluridisciplinaire HAL, est destinée au dépôt et à la diffusion de documents scientifiques de niveau recherche, publiés ou non, émanant des établissements d'enseignement et de recherche français ou étrangers, des laboratoires publics ou privés.

\section{(c)(1)}

Distributed under a Creative Commons Attribution| 4.0 International License 


\title{
The customers for document supply in pharmacology: a case study from INIST in France (part 3)
}

Pascal Bador (corresponding author)

Chérifa Boukacem-Zeghmouri

Thierry Lafouge

Hélène Prost

Joachim Schöpfel

\begin{abstract}
Purpose: The article investigates the customers for the document supply of print serials.

Approach: The study is based on data from INIST-CNRS for document supply requests in pharmacology. Data were collected from 1998 to 2005 (10,000+ customer accounts with $4.6 \mathrm{~m}$ orders).

Findings: The article provides information about the distribution of orders per customer type, about the geographical origin of customers, about the ordering trends among pharmaceutical customers and of pharmaceutical journals.

Originality: This is the last of three articles on a longitudinal study over 13 years on different aspects of the relationship between document supply and impact factor (citations) in pharmacology, a scientific domain with a high use of scientific information.
\end{abstract}

\section{Keywords}

Document supply, Pharmaceutical companies, Electronic Resources, Longitudinal Study, INIST, Journal usage.

\section{Paper type}

Case study.

\section{Introduction and issues}

Part 1 of this study analysed trends in requests for pharmaceutical journals received at INIST (from 1992 to 2003), which brought out distinct patterns among different groups of journals within our corpus (Boukacem-Zeghmouri et al. 2006). This was followed by an analysis of the relationship between document delivery from our corpus and the number of citations counted within each group (Bador et al. 2007). The third and final part of our research explores a different and equally significant aspect, namely, INIST's customers in the field of pharmacology.

This final part of our research aims to identify the main categories of users requesting pharmaceutical journals from INIST and their needs in qualitative and quantitative terms. In other words, the titles most frequently requested and how often, document 
ordering patterns by client category, and finally, the influence of the digital environment on demand. The last point, which we analyse over a six-year period, implicitly answers the question of trends in demand.

It should be pointed out that this final part of our research is not intended as a proposal for a study of usage among INIST's customers, which would be a very difficult matter given its size and diversity. Rather, the aim is to produce a quantitative analysis of ordering trends for the different customer categories and of patterns in these flows over a given period.

\section{The sample}

As in the two previous papers, the relevant data were supplied to us by INIST. A number of preliminary considerations had to be taken into account for these to be exploitable.

INIST has 10,270 customer accounts. Each customer account will have records of $n$ orders, whether these are satisfied from INIST collections or by a different backup supplier. Each order corresponds to an individual item, mostly articles but in some cases also reports, conference proceedings, theses or parts of books.

Our classification of the customers is based on a previous study (Salaün et al. 2000) and contains eight categories:

1. Corporate pharmaceutical companies

2. Higher Education

3. Research organisations

4. Hospitals, medical centres \& clinics

5. Information centres

6. Other corporate companies

7. Individuals

8. Others

The period taken for this study, 1999 to 2005 , was a little shorter than for the previous articles. The reason is that we needed full data to make up our corpus for processing. The period in question is particularly significant since it includes the period of concern for our study as a whole, in other words, the advent of mass electronic journal supply in the French market.

The customer file covers 10,270 accounts with at least one order for the analysed period; the same establishment may have several accounts. Based on the file data, we can characterise customers according to the type of establishment they belong to.

\begin{tabular}{|l|c|}
\hline \multicolumn{1}{|c|}{ Customer category } & Number of accounts \\
\hline Corporate pharmaceutical companies & 963 \\
\hline Higher Education & 1,678 \\
\hline Research organisations & 2,513 \\
\hline
\end{tabular}


Document3

\begin{tabular}{|l|c|}
\hline Hospitals, medical centres \& clinics & 390 \\
\hline Information centres & 185 \\
\hline Other corporate companies & 2,363 \\
\hline Individuals & 1,622 \\
\hline Others & 556 \\
\hline Total & 10,270 \\
\hline
\end{tabular}

Table 1: Breakdown of accounts per customer type (1999-2005)

The customer file also provides information about the sector(s) of activity. Nearly $12 \%$ of the accounts are from customers with activity in the field of pharmaceutics.

\section{Breakdown of orders among the customers}

From 1999 to 2005, INIST received 4,670,148 document requests. Figure 1 shows how these orders are distributed among the customers.

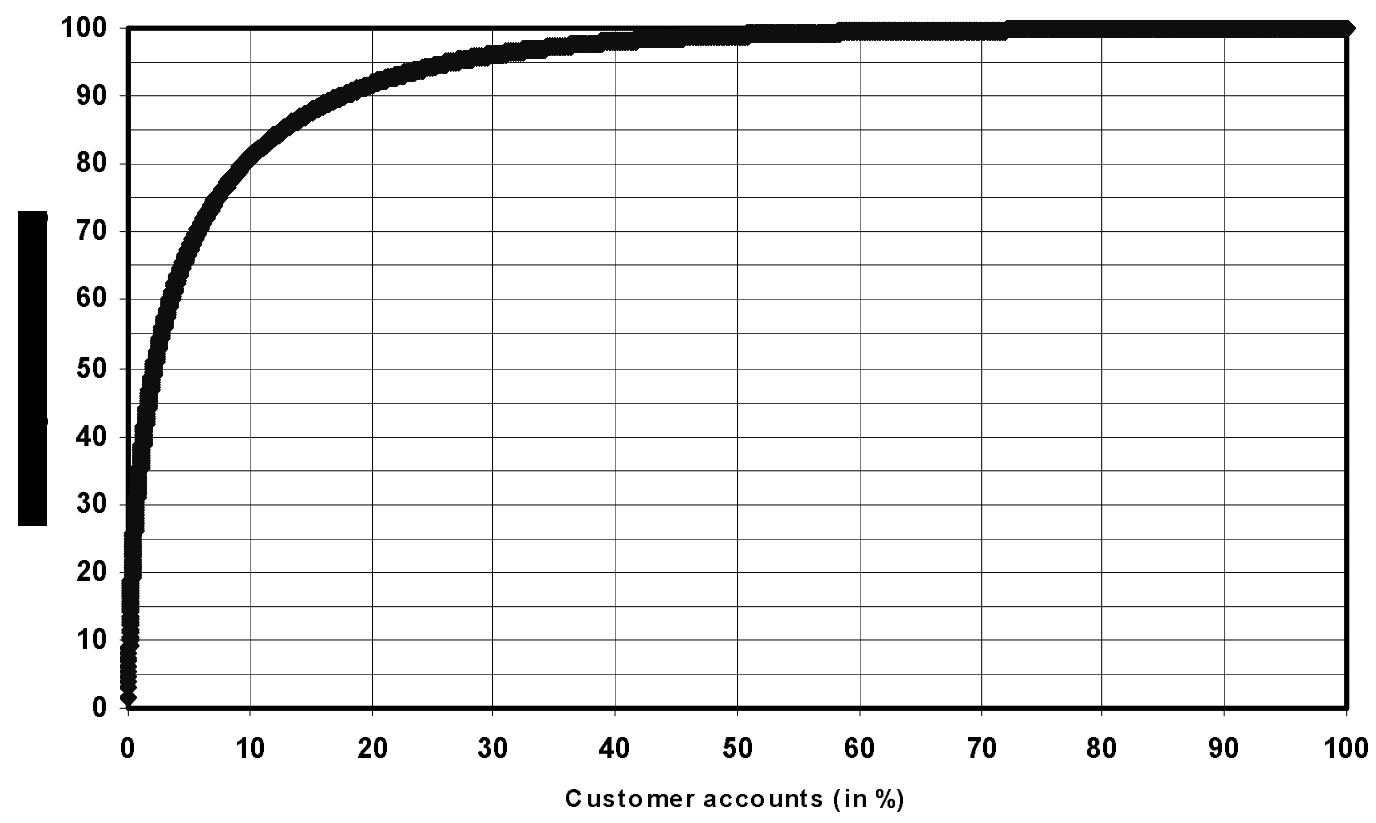

Figure 1: Breakdown of orders among the customers (1999-2005)

This graph shows that $80 \%$ of orders are placed from $10 \%$ of customer accounts. Albeit to a more concentrated degree, this echoes a pattern of distribution that is well known to specialists and researchers in the information sciences as the Pareto 
principle or " $80 / 20$ rule". The concentration is borne out by the figures showing that $27 \%$ of customer accounts generate $95 \%$ of orders.

This leads us to observe that the document ordering pattern here is similar to the pattern generally observed in the classic library model. In other words, we would argue that INIST, in this particular case, is operating as a library.

The same observation was made in a previous study covering the same scope (see Salaün et al. 2000), i.e., that the French document supply organisation was being used by its customers as a library and was reflecting the corresponding bibliometric patterns.

However, what emerged from our study is that the multitude of small customers and the large size of its major customers accounts affect INIST's functions as a library in a more concentrated and exaggerated manner.

\section{Distribution of orders per customer type}

Figure 2 below gives a clear idea of the distribution of orders received by INIST from its main customer types. Corporate pharmaceutical companies are in the lead with $28 \%$ of all orders. Next, are research organisations with $25 \%$, then other corporate companies with $20 \%$ and Higher Education with $17 \%$.

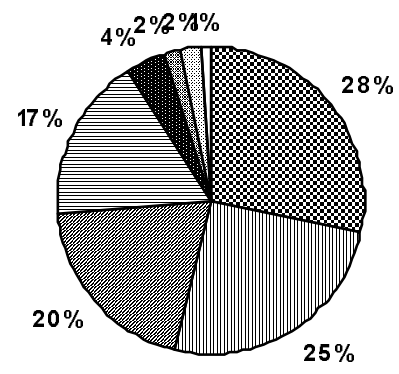

\begin{tabular}{|ll|}
\hline Corporate pharmaceutical companies & $\square$ Research organisations \\
国 Other corporate companies & $\square$ Higher Education \\
面 Information centres & $\square$ Others \\
$\square$ Hospitals, medical centres \& clinics & $\square$ Individuals \\
\hline
\end{tabular}

Figure 2: Distribution of orders per customer type (1999-2005)

The remaining nearly $10 \%$ of orders come from information centres (libraries), hospitals, individuals and other, unspecified customers.

\section{Breakdown of customers by geographic origin}

Table 2 below shows that like any French academic library, the vast majority of accounts - about $90 \%$ - are from customers situated in France. International customers are mainly European, highly dispersed and small in numbers. 


\begin{tabular}{|l|c|c|}
\hline \multicolumn{1}{|c|}{ Country } & Number of accounts & In \% \\
\hline France & 9,229 & 89.86 \\
\hline Italy & 207 & 2.02 \\
\hline Belgium & 131 & 1.28 \\
\hline Switzerland & 60 & 0.58 \\
\hline Other countries & 643 & 6.26 \\
\hline
\end{tabular}

Table 2: Breakdown of customers by geographic origin (1999-2005)

These figures and observations strengthen the conclusion that INIST appears to be operating as a national scientific library, since it operates for, or, more accurately, is approached by, primarily French customers. However, this situation started to change. From 1998 to 2005, international customer accounts doubled, increasing from 6\% to $12 \%$. This trend will probably be reinforced by three recent decisions: since 2006 the INIST catalogue has been indexed by Google (cat.inist), the orders via Google can be paid online, and in March 2007 INIST added secure electronic delivery via Google to its document supply portfolio.

\section{Breakdown of pharmaceutical / non pharmaceutical accounts}

Customers from the pharmaceutical sector represent $9 \%$ of all INIST accounts (see table 1). Compared to the distribution of orders by customers (see figure 2), it is clear that the importance of these customers for INIST is high; nearly one third of all documents were ordered by this category:

\begin{tabular}{|l|c|c|}
\hline \multicolumn{1}{|c|}{ Typology } & Accounts (in \%) & Orders (in \%) \\
\hline Pharmaceutical companies & $9 \%$ & $28 \%$ \\
\hline Others & $91 \%$ & $72 \%$ \\
\hline
\end{tabular}

Table 3: Accounts and orders from the pharmaceutical companies (in \%)

About $95 \%$ of these accounts are from French customers. But in contrast to what we observed above for the whole range of INIST customers, the 5-6\% orders from international pharmaceutical accounts remained stable over the period. There is no indication that INIST has strengthened its position in the highly competitive international market for information provision to pharmaceuticals.

\section{Evolution of document supply}

Our first study described the overall evolution of the INIST document supply, especially the steady and significant decline in the number of documents supplied from 1999 on, when the market for digital periodicals began to expand (BoukacemZeghmouri et al. 2006). 


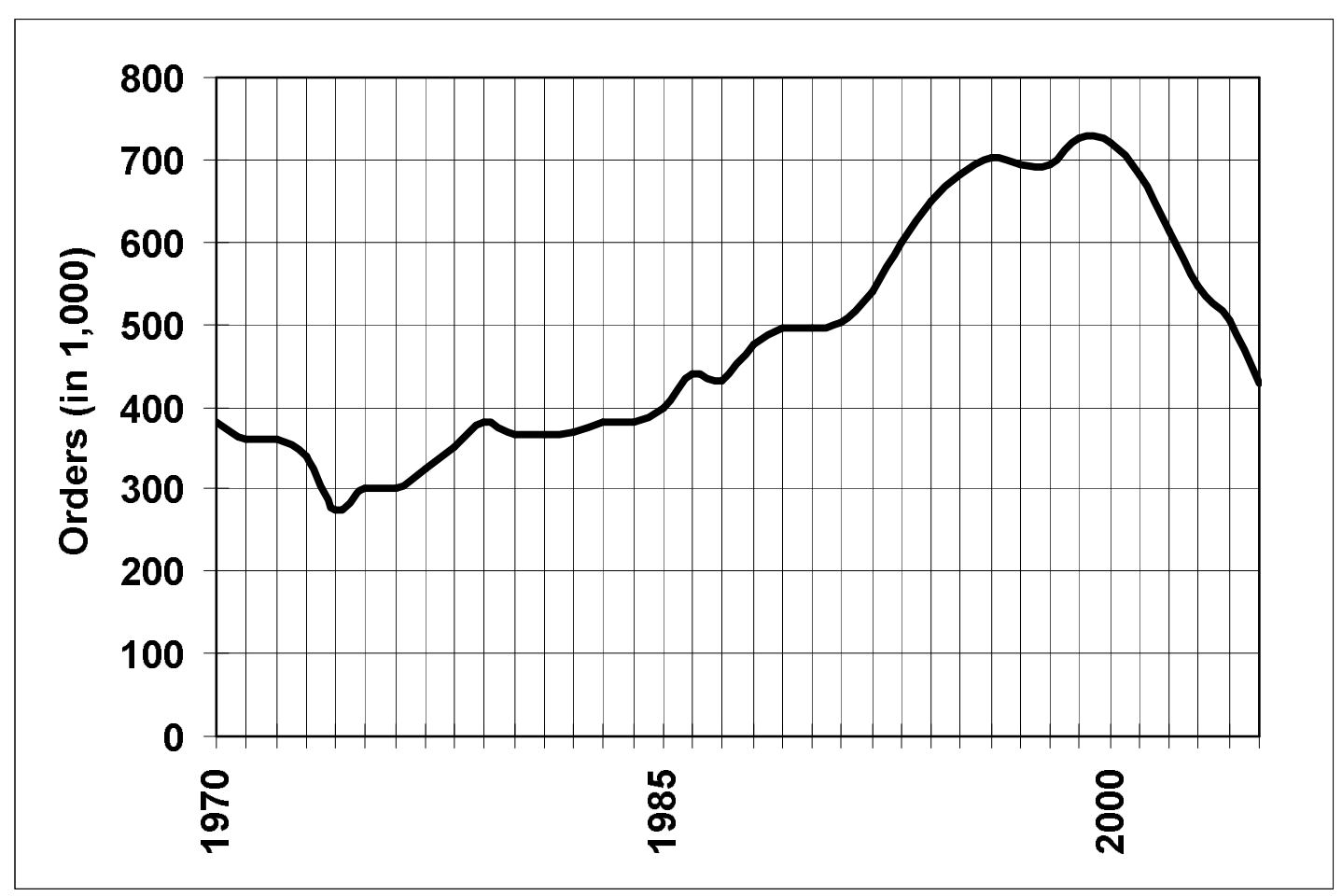

Figure 3: Articles ordered from INIST (1970-2005)

Our data showed that the decline accelerates with time, with a drop of $40 \%$ in the last five years. This is readily accounted for by the supply of electronic journals just as steadily increasing and gaining market share. This in turn is easily explained by being an area where information and research activities are undertaken in a climate of competitive urgency where immediate access to documents is at a premium. Figure 4, below, offers further insight into this situation by showing how the pattern evolved from 1998 to 2005 . 


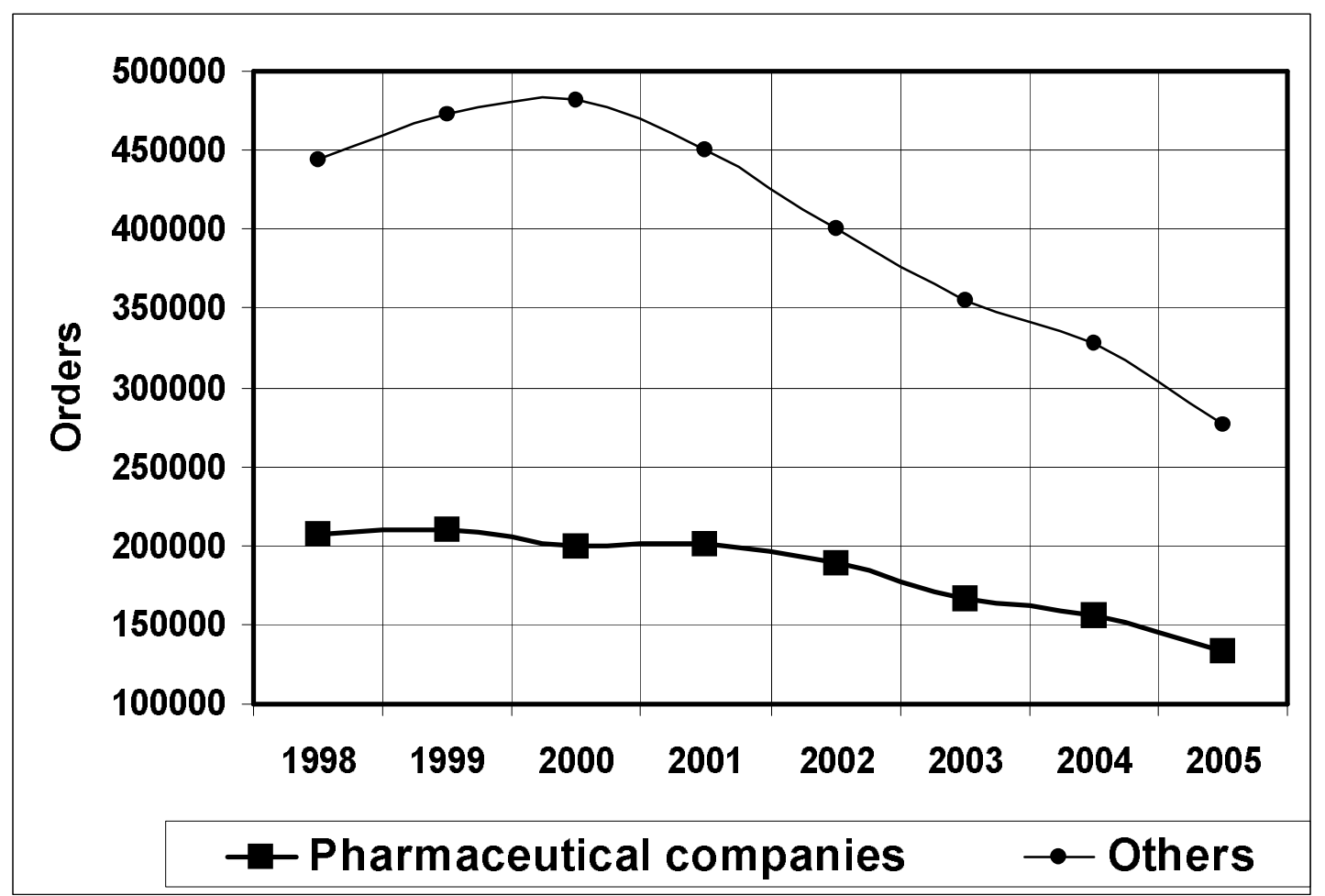

Figure 4: Orders from pharmaceutical and non pharmaceutical customers (1998-2005)

The development of the supply requests is roughly the same, except that the pharmaceutical companies ceased to increase their document orders from 1998 on while the orders from other customers continued to grow until 2000. However from 2001-2002 on there is little difference.

\section{Ordering trends among the ten largest pharmaceutical groups}

Nevertheless, differences do exist but they are not related the sector of activity but to the companies' size. We now look into ordering trends among the ten largest pharmaceutical groups by sales ${ }^{1}$. Together, these laboratories represent $3 \%$ of all INIST customer accounts, or $23 \%$ of the pharmaceutical companies' accounts. In terms of document supply; their importance is significant: they cumulated $12 \%$ of the overall number of requests 1998-2005.

Figure 5, below, shows that the decline among the ten largest pharmaceutical groups started slowly in 2000 and became much more manifest from 2002 on.

\footnotetext{
${ }^{1}$ See http://en.wikipedia.org/wiki/Pharmaceutical (accessed March 11, 2007).
} 


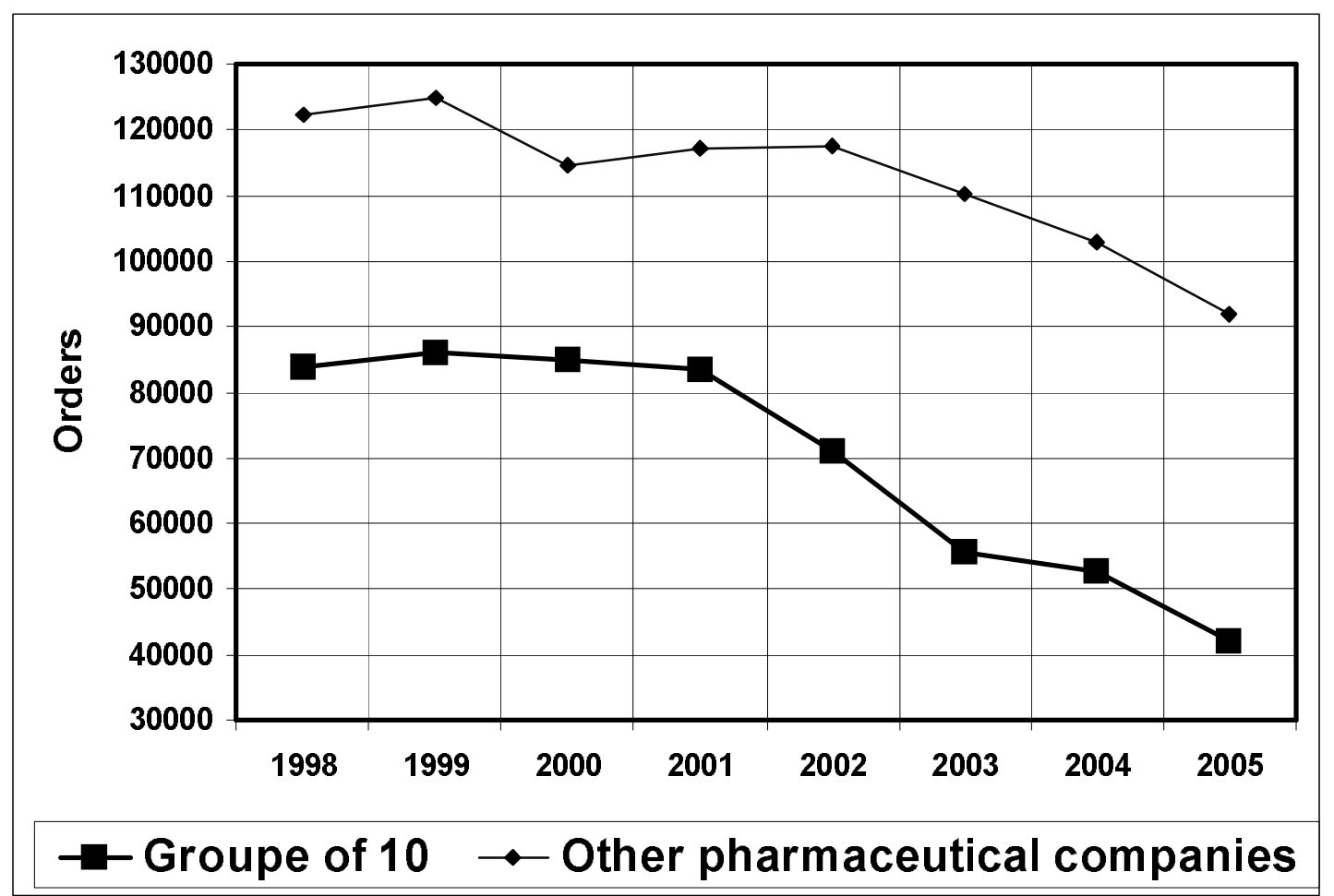

Figure 5: Pharmaceutical customers: breakdown of companies' size (1998-2005)

The average rate of decline in orders from these laboratories between 1998 and 2005 - 50\% - was greater than the overall decrease $(40 \%)$ and double the average for the smaller pharmaceutical companies $(25 \%)$ or the other corporate companies $(20 \%)$. Even so, the decline differs between the ten groups, with a range from $-6 \%$ to $-82 \%$.

This deserves to be investigated in more detail. The year 2000 saw a rapid increase in the availability of digital journals in France. This may explain the fact that the impact was not felt until then and not yet to a significant extent. However, the spectacular decline observed after 2000 can be accounted for by the launch of academic services such as BiblioInserm and more commercially oriented services such as Elsevier's ScienceDirect.

It seems entirely legitimate to suggest that these large, well-endowed multinational groups ("Big Pharma"), whose intensive research activities are highly correlated with information activities, began to subscribe to electronic periodicals and, consequently, increasingly abandoned print publications. We therefore suggest that these large groups have organised access to online document resources as a matter of strategy, in accordance with the needs of their research communities.

A discussion concerning this observation may be found in Kesarab's study (2006) on the library at Novo Nordisk. It is shown here that Elsevier's "pay per view" service is becoming increasingly popular with the library's users and that this is contributing to the decline in orders.

\section{Supply of pharmaceutical journals}

The object of our first two studies was a corpus of 89 pharmaceutical serials with an ISI impact factor (see Boukacem-Zeghmouri et al., 2006 and Bador et al., 2007). 


\section{Document3}

Together, these journals generated 151,090 or $3.24 \%$ of overall orders $1999-2005$, with a steady decline of $42 \%$ in the same period (see figure 6 ).

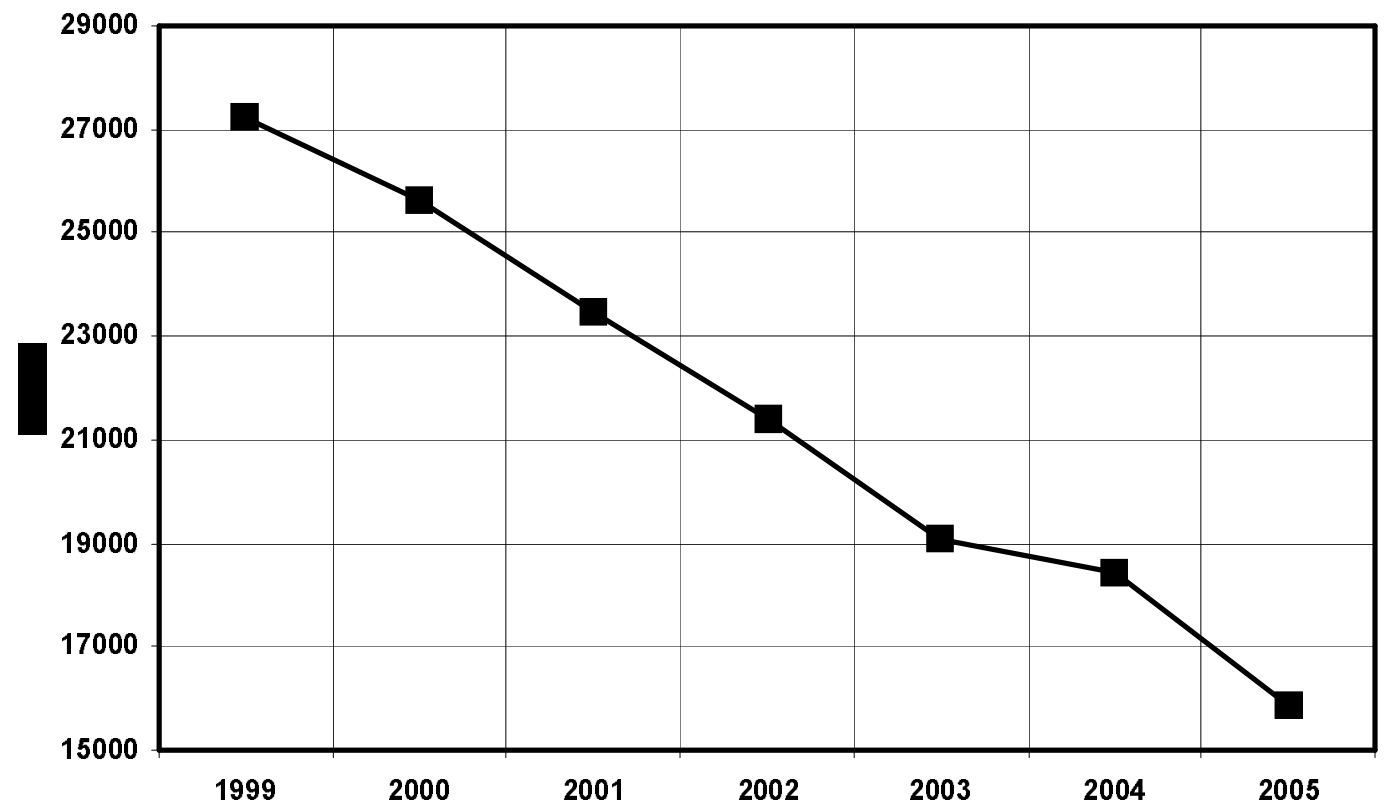

Figure 6: Evolution of supply of 89 pharmaceutical journals (1999-2005)

This trend is roughly the same as for all incoming requests. In the same time, the number of customer accounts for this corpus is also decreasing by $30 \%$ (see figure 7 ). The linear correlation coefficient between these two distributions, "document orders" and "number of customers", works out at 0.96. Our previous results, taken together with this very high correlation, clearly show that it is not because these journals have become less attractive that orders have declined. 
Document3

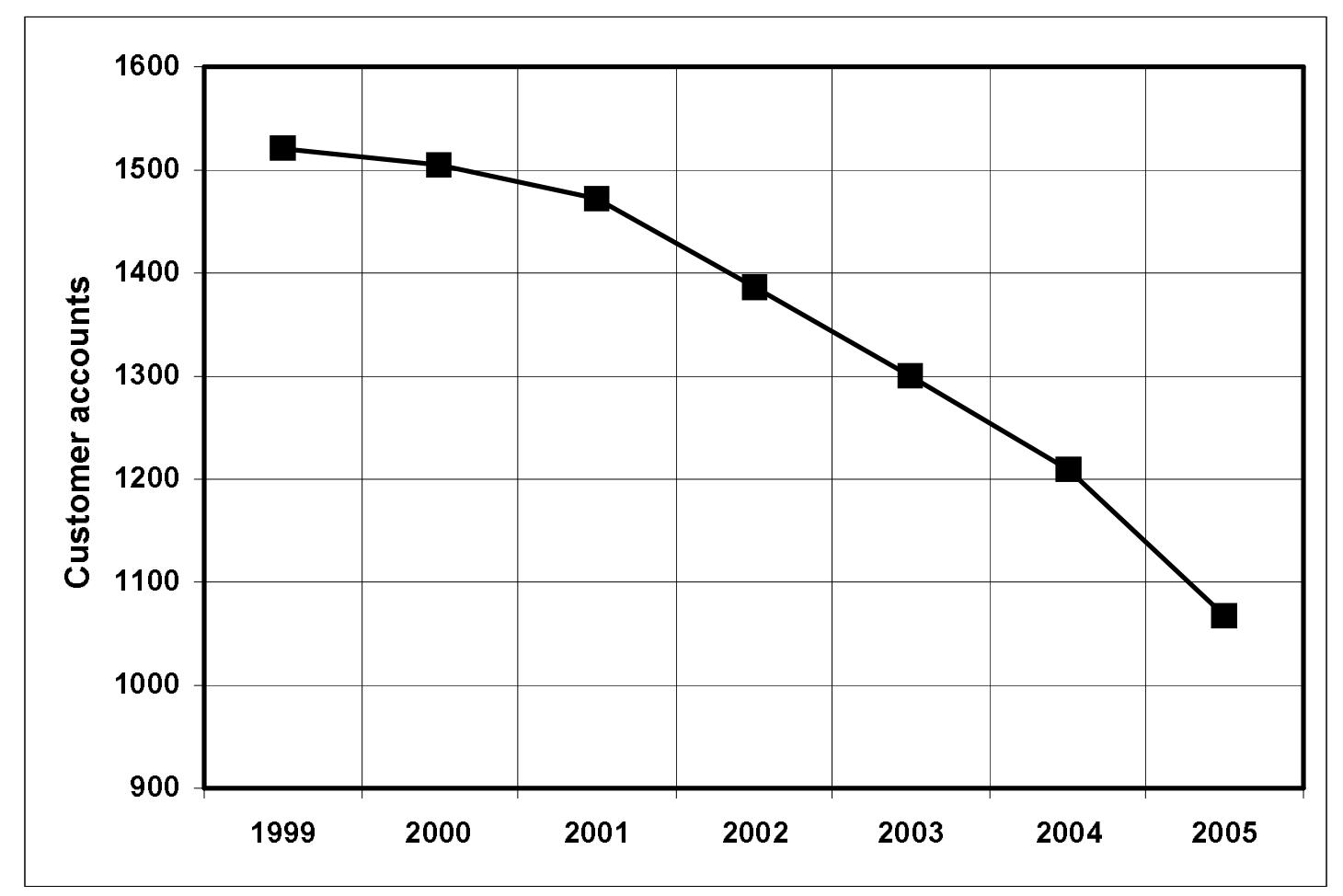

Figure 7: Trends in customers for 89 pharmaceutical journals (1999-2005)

However, the typology of customers for this corpus is different. Compared to the breakdown of all orders, the proportion of corporate pharmaceutical customers is significantly higher (see table 4).

\begin{tabular}{|l|c|c|}
\hline \multicolumn{1}{|c|}{ Customer category } & Overall & $\mathbf{8 9}$ journals \\
\hline Corporate pharmaceutical companies & $28 \%$ & $56 \%$ \\
\hline Higher Education & $17 \%$ & $6 \%$ \\
\hline Research organisations & $25 \%$ & $15 \%$ \\
\hline Hospitals, medical centres \& clinics & $2 \%$ & $1 \%$ \\
\hline Information centres & $4 \%$ & $2 \%$ \\
\hline Other corporate companies & $20 \%$ & $18 \%$ \\
\hline Individuals & $1 \%$ & $1 \%$ \\
\hline Others & $2 \%$ & $1 \%$ \\
\hline
\end{tabular}

Table 4: Distribution of orders per customer type for 89 pharmaceutical journals (1999-2005)

$96 \%$ of these journals are ordered by all customer types but their main interest is for those in the pharmaceutical sector, not for a general public or scientific readership. 
The analysis of the evolution by customer typology reveals an interesting fact: mainly because of the development of access to online resources 1999-2005, the orders from pharmaceutical companies $(-47 \%)$, universities $(-61 \%)$ and research organisations ($66 \%$ ) went down. In the same period, the requests from other corporate companies $(+12 \%)$ and from information centres $(+123 \%)$ increased.

Finally, we compared the information needs of the different customer categories to the four groups of journals ("quarters") described in our $2^{\text {nd }}$ article (Bador et al., 2007).

\begin{tabular}{|c|c|l|c|c|c|}
\hline Quarter & Journals & Description & $\begin{array}{c}\text { Pharmaceutical } \\
\text { companies }\end{array}$ & $\begin{array}{c}\text { Other } \\
\text { companies }\end{array}$ & $\begin{array}{c}\text { Higher Education } \\
\text { and public research }\end{array}$ \\
\hline 1 & $21 \%$ & $\begin{array}{l}\text { Most cited, } \\
\text { most requested }\end{array}$ & $\downarrow$ & $\downarrow$ & $\downarrow$ \\
\hline 2 & $18 \%$ & $\begin{array}{l}\text { Less cited, } \\
\text { most requested }\end{array}$ & $=$ & $=$ & $\uparrow$ \\
\hline 3 & $53 \%$ & $\begin{array}{l}\text { Less cited, } \\
\text { less requested }\end{array}$ & $\uparrow$ & $\uparrow$ & $\uparrow$ \\
\hline 4 & $8 \%$ & $\begin{array}{l}\text { Most cited, } \\
\text { less requested }\end{array}$ & $=$ & $=$ & $=$ \\
\hline
\end{tabular}

Table 5: Importance of the different journal types by customers (1999-2005)

The trends of relative importance are consistent (see table 5): over the years, the high quality (measured by the ISI impact factor) and highly requested journals became less important for document supply. The reason is not hard to find: these are the titles of the publishers' core collections included in the customers' deals with publishers.

In the same time, the group of less cited, less requested journals gain relative importance, even if the overall number of requests diminishes. Probably, these journals - more than the half of all titles of our corpus - are part of the "long tail" of scientific journals that are not necessarily included in the licences negotiated with the publishers.

It maybe that the access to these "long tail" journals of lesser scientific interest will remain one of the future challenges both for publishers and for STI suppliers such as INIST.

\section{Conclusion}

The results we presented above contribute to a better understanding of the market for electronic scientific information.

Firstly, the role of INIST as an important academic and scientific library appears to be confirmed by the usage and the structure of its customers. In a national environment without any other comparable establishment, INIST becomes a kind of first-choice backup library. About $90 \%$ of its customers are French; $16 \%$ of its accounts are from university libraries that mainly order through the French ILL network PEB. In other words, INIST is expected to supply those items that aren't available through the print and digital subscriptions of the national scientific community. 
Secondly, we showed that the pharmaceutical corporate customers, especially those from the "Big Pharma", display the most important activity and simultaneously, its most important decrease. One explanation is their specific corporate culture is characterized by strong economic competition and a R\&D activity under constant pressure. These large customers are clearly turning away from INIST and towards digital distribution of commercial scientific information, especially from publishers, database producers and other vendors that offer high-speed, high-quality, copyrightcompliant digital supply from pharmaceutical and biomedical core collections to their laboratories and $\mathrm{R} \& \mathrm{D}$ teams globally.

Thirdly our data provides evidence for a breaking point that, although recent, merits attention. The evolution of the market of scientific information may sooner or later challenge our results with INIST gaining more international customers and becoming less dependent on the national market and its development.

Fourthly, the period of our study reveals crucial risks or opportunities, whether one adopts the publishers' or the suppliers' point of view. In particular, the analysis of the four groups of the corpus of 89 pharmaceutical journals illustrates that the subscription to digital resources principally affects the supply of high-quality, most cited and most requested titles while others with lower impact factors and more marginal order numbers are less affected. Sticking to a logic of "niches", publishers may be expected to develop specific offers for this "long-tail" part of their catalogues. The Novo Nordisk experience seems to confirm this perspective (Kesarab, 2006). If this transpires, the decrease of traditional document supply would continue.

On the other hand, the slower decline among smaller pharmaceutical companies seems largely accounted for by financial reasons, e.g. less investment in the creation and running of a service of documentation, and less resources for the subscription to print and e-serials, especially "big deals". Nevertheless, it is also apparent in organisations for which INIST provides not only document supply but also other functions in documentation, e.g. information searching, handling incomplete or difficult requests, acquiring documents from a multitude of sources, connecting the INIST database and its order form to the customer's in-house information system.

Based on the results of the last part of our longitudinal study we may state that INIST as a scientific library and major supplier of scientific and technical information, just as other public structures in the same sector, has two choices: either it continues to suffer from the evolution of the corporate information market, or it proves to be able to anticipate the forthcoming strategy of commercial publishers, refocuses its role and develops new and customized expert services and evaluation and/or current awareness services.

\section{Bibliography}

Bador, P., Boukacem-Zeghmouri, C., Lafouge, T., Prost, H. and Schöpfel, J. (2007), "A cartographic analysis of the correlation between document supply and citations in pharmacology: a case study from INIST in France (part 2)", Interlending \& Document Supply, Vol.35, No.1, pp.7-14.

Boukacem-Zeghmouri, C., Bador, P., Lafouge, T., Prost, H. and Schöpfel, J. (2006), "Analysis of the downward trend in document supply in pharmacology: a case study from INIST in France (Part 1)", Interlending \& Document Supply, Vol.34, No.4, pp.177-185. 
Document3

Kesarab, H. (2006), "The impact of e-resources on document supply in a corporate pharmaceutical library: the experience of Novo Nordisk", Interlending \& Document Supply, Vol.34, No.3, pp.105-108.

Salaün, J.M., Lafouge, T. and Boukacem, C. (2000), "How far does demand for scientific articles reflect development in electronic publishing? An example from the Institut de 1'Information Scientifique et Technique (France)", Scientometrics, Vol. 47, No.3, pp.561-588.

\section{The authors}

Pascal Bador is a Lecturer at Universite Claude Bernard Lyon 1 and member of the ELICO research group.

Université de Lyon, France; Université Lyon 1, équipe ELICO, 43 boulevard du 11 Novembre 1918, F-69622 Villeurbanne, France.

Pascal.Bador@univ-lyon1.fr

Chérifa Boukacem-Zeghmouri is a Lecturer at Université Charles de Gaulle Lille 3 and member of the GERIICO and ELICO research groups.

Université Charles de Gaulle Lille 3, GERIICO, Domaine Universitaire du Pont de Bois, Rue du Barreau, F-59653 Villeneuve d'Ascq, France.

boukacemc@yahoo.fr

Thierry Lafouge is Professor at Université Claude Bernard Lyon 1 and a member of the ELICO research group.

Université de Lyon, France; Université Lyon 1, équipe ELICO, 43 boulevard du 11 Novembre 1918, F-69622 Villeurbanne, France.

Thierry.Lafouge@univ-lyon1.fr

Hélène Prost is a librarian at INIST-CNRS and expert of the evaluation of collections and document supply.

INIST-CNRS, 2 allée du Parc de Brabois, F-54519 Vandouvre-lès-Nancy Cedex, France.

prost@inist.fr

Joachim Schöpfel is Head of the E-publishing and Document Supply Department at INIST-CNRS and Lecturer on Scientific Information at Université Nancy 2.

INIST-CNRS, 2 allée du Parc de Brabois, F-54519 Vandouvre-lès-Nancy Cedex, France.

schopfel@inist.fr 